\title{
THE CONSTITUTION AND THE EMPEROR SYSTEM: IS REVISIONISM ALIVE?
}

\author{
YoIchI Higuchi*
}

INTRODUCTION

I have been asked to treat the following subject: The Constitution and the Emperor ${ }^{1}$ System: Is Revisionism Alive? As you may know, the conservative and authoritarian movement for constitutional revision, ${ }^{2}$ which appeared in the 1950s, called for the revision of three essential points of the 1947 Constitution. The first demand was for the reinforcement of the status of the emperor and for the weakening, if not the suppression, of the principle of popular sovereignty. The second demand was for an official rearmament, which runs counter to the celebrated pacifist Article 9. The third demand aimed for a restoration of the old patriarchal type of family system, which contradicted the notions of the dignity of the individual and the equality of the sexes enunciated in Article 24.

Since the electoral defeat of this revisionist movement, especially in 1955 and 1956, the problem of the emperor has remained, as it were, absent from constitutional strife. However, the chain of events set in motion by the long illness and subsequent death of Emperor Hirohito in 1988-1989 has revived both theoretical and practical interest in the roles that the emperor once played, now plays, and should, or rather should not, play in the national life of the Japanese archipelago.

Is revisionism still alive with regard to the status of the emperor? Answers will vary depending on the definitions accorded to the word "revisionism."

If we adopt the current usage of the term-that is, if we consider an explicit reform of one or several provisions of the Constitution-then it is not realistic to anticipate in the relatively near future the enactment of any changes in the status of the emperor. If, on the other hand, we consider concealed revisionism, that is, the attitude of the holders of political power who would ignore the rules imposed by the Constitution and attempt

\footnotetext{
Copyright (C) 1990 by Law and Contemporary Problems

* Professor, Faculty of Law, University of Tokyo.

1. The word "emperor" cannot translate well; as a matter of fact, the character is sui generis of the Japanese tenno. On this point, see T. Fukase \& Y. Higuchi, Le Constitutionnalisme et ses Problemes au Japon-A Comparative Approach 49 (1984).

2. On constitutional revisionism since the 1950s, see id: Higuchi, Un Grand Paradoxe, ou la Notion d" "Occident" dans les Problemes Constitutionnels Actuels au Japon, in 35 Pouvolr 23 (1985).
} 
therefore to have us forget the Constitution's fundamental value, then the response is not so simple.

\section{Explicit Revision Blocked: A Wide Consensus Concerning THE Symbolic EMPERor}

How are the prerogatives of the king and of the armed forces, which, while under the king's control, sustain him, to be regulated? These were the two points crucial to modern constitutionalism that were at stake during the period of its advent. It would be superfluous to recall the tragic, yet incontestable, fact that regicides were necessary to put a distinct end to the ancient regimes in England (1649) and France (1793). I will, therefore, only allude to, as examples, a passage of the Bill of Rights reproaching James II for having recruited armies without the consent of Parliament and, as for France, the great debates concerning the question of royal veto powers as well as the adoption of clauses concerning public forces, including the National Constituent Assembly's famous Article renouncing war.

Under the "Great Empire of Japan" that replaced the reign of the feudal shogunate, the Imperial Charter of 1889 consecrated the sovereignty of the emperor according to divine principle. The constitutional status of the emperor varied according to the times, yet the text remained untouched from 1889 until 1945. We indeed witnessed the rise of constitutional liberalism from about the year 1900. Yet the experience of a government responsible to the Imperial Diet proved ephemeral, lasting only from 1924 to 1932. The remains of liberalism were finally and brutally extinguished in 1935 when the liberal constitutional doctrine of Professor Minobe was condemned as opposing the sacrosanct kokutai, which signified the divine legitimacy of the emperor, holder of all state powers.

As for the imperial armies, they were, during the entire period of the application of the Charter, placed beyond the supervision of the government and, a fortiori, of the Diet; the armies, by virtue of the principle of "the independence of the military command," responded directly to the emperor. The invasion of the Chinese continent launched in the 1930s and the attack on Pearl Harbor were the direct consequences of the omnipotence of the imperial armies, which were able to crush all opposition in the name of the emperor, the living deity.

It was thus natural, legitimate, and absolutely necessary for the Constitution of 1947 to change from the outset the two essential elements of the theocratic militarism of the pre-1945 Empire of the Rising Sun. Hence appeared, on the one hand, the proclamations of popular sovereignty and of a symbolic emperor in lieu of a sovereign one, and, on the other hand, the renunciation of war and of armament.

I do not intend to discuss in detail the thesis according to which the 1947 Constitution was imposed, indeed dictated, by the Americans, a thesis dear to the revisionists of the 1950s and still upheld today by a few important figures, 
among them former Prime Minister Nakasone. I wish simply to establish three essential points with regard to the above thesis.

First, the Constitution was indeed imposed by General MacArthur's team and, through it, by international opinion, in opposition to the will of the contemporary Japanese leaders, who insisted upon the maintenarice of the kokutai, the status of the emperor invested with all of the powers of the state. Second, the Constitution was nonetheless favorably received by public opinion. A poll taken of "enlightened persons" by the major daily Mainichi newspaper revealed that 85 percent of those surveyed were in favor of the new, symbolic status of the emperor that had replaced his previous sovereign standing. Third, it remains true that the Japanese people were not able to impose their own constitution on their rulers. Even today, this constitutes the weakness of liberal, democratic Japan's fundamental law, although the nation apparently benefits from the massive stability afforded by its economic development.

Let me close this parenthetical comment by touching on the revisionism of the 1950s, which, as I noted at the beginning of this article, hoped to call openly into question the three major choices crowned by the Constitution of 1947. This revisionism, of a highly authoritarian nature, was, however, unable to find its reflection in either public opinion or at the polls. Indeed, since the Hatoyama government's revisionist program suffered defeat in the legislative elections of 1955 and the senatorial elections of 1956, no government has dared, out of fear of losing votes, to call openly for a revision of the Constitution.

However, the 1980s witnessed a sudden revival of constitutional revisionism. The prime minister from 1982 to $1987, \mathrm{Mr}$. Nakasone, an avowed revisionist since the 1950 s, now emphasizes the need to recall into question the "constitutional taboo" in order to undertake a "settlement of accounts of the postwar period."

The growth of revisionism in the $1980 \mathrm{~s}$ had both structural and conjunctural, or circumstantial, causes. The causes were structural in the sense that we are now in the presence of neonationalism based on pride in having become an "economic power", and of a certain nippocentrism fueled by the sentiment that Japan no longer has anything to learn from other countries. Its causes were conjunctural in that the movement found an energetic standard-bearer in the person of Prime Minister Nakasone, who led the Liberal Democratic Party ("LDP") to an unprecedented majority (304 seats out of 512) in the lower chamber.

Are there any differences between the revisionism of the 1950 s and that of the 1980s? It is a fact that the three decades separating the two periods have brought many changes to the nation; we need only recall the formidable economic growth and the transformation of the social environment that it involved. A pure and simple return to a sovereign emperor and, a fortiori, to an emperor as living deity, may thus no longer be seriously envisaged. 
The symbolic emperor is in effect the object of a wide consensus among both the majority and the opposition. At least in its appearance, the revisionist program of the 1980 s no longer contains any striking features (for example, the report presented in 1982 by a section of the LDP's Constitution Commission). It is proposed, for example, to revise Article 7, eighth phrase, which enumerates as one of the emperor's honorary activities the "attestation to the instrument of ratification of international treaties," in order to replace it with a new formulation according to which the emperor will ratify treaties. Attention should be paid, in this respect, to the very important fact that the revisionists have already attained their objective in daily practice. On the diplomatic level, the symbolic emperor today in effect performs the role of head of state, although there subsists a dispute over theoretical exegesis, to which we shall return shortly. It would be appropriate at this point to add a remark concerning the characteristics, indeed paradoxes, of constitutional revisionism in postwar Japan.

There are essentially three such paradoxes. The LDP has never completely rallied itself to the liberal and democratic constitution, although it is by virtue of the constitution that the party has maintained a monopoly of power since its foundation in 1955. In effect, the LDP has stated in its official program its intention to "elaborate an autonomous constitution," the phrase implying that the present constitution was "imposed" by the foreign forces. Hence, the Japanese conservatives show no great desire to conserve their fundamental law.

Let us consider the second paradox. The LDP is not so faithful to its official program. The party brings together a variety of political persuasions; its members of parliament are sufficiently sensitive to public opinion to avoid the sort of ideological struggle that might turn away their electorate. Successive prime ministers have hence without exception ultimately declared their intentions "not to undertake a revision at this point."

Finally, let us consider the third paradox, which is no less important than the first two. The conservative elected officials' reluctant marriage to the constitution is of necessity a fragile one. It should be noted that Japanese "liberals" tend to be "liberal" even with regard to antiliberals. Let us recall the situation in the 1930s, when liberals, who because of their pro-Western orientation were more or less opposed to Japan's militarist-nationalist adventurism, finally accepted such policies without great resistance. In the West, such people would have been denounced as either opportunists or traitors to liberal ideals.

Given the above observation, it is too soon to offer any predictions about the ebb and flow of revisionism. I wish simply to state that, with regard to the status of the emperor, a radical change is not at present foreseeable. 


\section{Concealed Revisionism: A Certain Continuity in the Status of The EMperor Between the Two Fundamental Laws}

\section{A. More than a "Symbol": The Problem of Contra Constitutionem Practices}

In Japanese juridical culture, interpretation is greatly favored over legislation. This statement applies more on the level of the fixed constitution than on that of parliamentary laws. The Imperial Charter of 1889 underwent no revisions in its 55-year lifetime.

Thus, in order to measure exactly the real political and social repercussions of the revisionists' demands, one must consider the issue of constitutional interpretation in practice. In effect, the revisionists often achieve in practice what they have been unable to realize through explicit textual revision.

At issue is what I call "concealed revision." Before analyzing two typical examples of this practice, I would like to re-examine, with regard to the question of the status of the emperor, the two opposing propositions argued at the time of the drafting and implementation of the 1947 Constitution. One thesis emphasized the continuity that its proponents held should exist between the fundamental law of 1889 and the new Constitution of 1947. The second thesis called for a clean break between the two constitutions. The revisionist movement, despite its occasionally nuanced statements, seems to want to establish a certain continuity with pre- 1945 practices.

As I have already suggested, the Japanese government finally accepted the Constitution in 1945-1946 only in order to preserve the Imperial system and to protect the person of the emperor, who risked accusation as a war criminal. One minister of the time even called the new constitution a "lightning rod" to protect the Imperial regime.

Of which Imperial regime was he speaking? The government had at first resisted the initiatives of General MacArthur's team in the name of that which it felt to be the very essence of the Imperial regime, that is, the kokutai. Yet the government finally accepted the Constitution in the name of the same kokutai.

This paradox was rendered possible by the ambiguous nature of the word kokutai. Indeed, the word may signify either imperial sovereignty in the juridical sense of the term, or the national belief, of a moral or sentimental order, in the emperor. Preservation of the kokutai in its latter sense ultimately involved a renunciation of the former sense of the term.

The kokutai in its juridical sense was indeed incompatible with the Constitution of 1947, which proclaims the sovereignty of the people, and which defines the role of the emperor as being the "symbol of the Japanese State and of the unity of the Japanese people." Nevertheless, a few impassioned debates were required to clarify matters. Two fundamental lines of argument can in effect be distinguished. 
On the one hand was the continuity thesis upheld by Tomoo Otaka, a legal philosopher who hoped to minimize the extent of the changes caused by the promulgation of the Constitution of 1947. Otaka emphasized the notion that there is a certain continuity of the "sovereignty of nomos (law)," and that this continuity bridges the apparent fissure between the old and new constitutions.

On the other hand was the rupture thesis of Toshiyoshi Miyazawa, constitutionalist and successor of Minobe. Criticizing Otaka's thesis, Miyazawa developed his theory of the "August Revolution," 3 according to which Japan had already in August 1945 renounced the juridical interpretation of kokutai by accepting the Potsdam Declaration, which demanded Japan's adherence to the universal principle of democracy.

Otaka's doctrine supports those who do not wish to recognize the abolition of the kokutai in the juridical sense of the word, and who hope to consolidate their position by emphasizing the continuity of the "sovereignty of nomos." Miyazawa's doctrine, on the contrary, bears the great distinction of having stood for the establishment of popular sovereignty for its own sake; such popular sovereignty signified by definition the pure and simple negation of the juridical kokutai.

One can and must ascertain, upon reading the text of the Constitution of 1947, that the kokutai in its juridical sense has been abolished. It remains to be verified whether the kokutai in its moral sense has also been changed. I shall later return to this problem, which, due to the events of 1988-1989, has assumed a highly topical character. But before doing so, I would like to insist upon the juridical aspect of the problem and show how, forty years after the implementation of the Constitution, the continuity thesis has reappeared to justify practices whose constitutionality has been called into question by specialists in constitutional law. I will cite but two examples. The first concerns the idea of the head of state. Is the symbolic emperor no longer the head of state? Or, on the contrary, is he still the head of state, although his role as such has become merely honorary?

In order to be characterized as a head of state, a monarch or president must have the competence, be it real or nominal, to represent his state in its external relations. We have already taken note of one example of proposed constitutional revision in this domain. The Constitution stipulates, in the eighth phrase of Article 7, that the emperor is to attest to the instrument of ratification of international treaties. However, the function of "concluding international treaties," and consequently of ratifying them, is assigned to the cabinet of ministers by the second phrase of Article 7. A clear distinction has been drawn between "ratification" itself and the "attestation" to that ratification.

3. On the theory of the "August Revolution" developed by Toshiyoshi Miyazawa, see T. Fukase \& Y. Higuchi, supra note 1, at 24-27. 
The Constitution was hence designed to depict the image of a monarch whose competences have been reduced to a minimum. The text thus clearly stresses the break with the imperial regime consecrated by the charter of 1889: A symbolic emperor based upon the principle of popular sovereignty has replaced the sovereign emperor who was termed a living god.

However, the situation is different in practice. The government insists upon a very careful wording of various diplomatic instruments. For example, the emperor only "attests" to an ambassador's letters of accreditation, which are issued by the cabinet of ministers. Yet such letters are all the same so skillfully drafted as to lead the foreign head of state who receives them to think that they were issued by the emperor himself. Thus, in practice, attempts are made to have the emperor play the role of head of state.

Let us now consider the second example, which concerns the problem of the separation of church and state. The divorce of Shintoism from the state, one of the major objectives of the postwar democratization process, was effected in order to eliminate the specter of that political-military-ideological giant, the "Great Empire of Japan." It is in light of this that debate has been focused on the government's decisions concerning the series of ceremonies that took place (and that will continue until the official celebration of the new Emperor's accession to the throne, scheduled for the autumn of 1990) in the wake of the death of Emperor Hirohito.

The problem concerns mainly the official funeral services for the late Emperor. ${ }^{4}$ According to critical observers, these services violated the principle of the separation of religion and state $^{5}$ by inadequately distinguishing between the official rites and the imperial family's Shinto rites. The Communist members of parliament and the representatives of the Japanese Federation of Bar Associations boycotted the official services, which were attended by the representatives of 159 countries. The majority of the Socialist members of parliament avoided the Shinto rites and took part in only the nonreligious services.

A similarly heated debate is certain to occur with respect to the new Emperor's rites of accession, planned for the autumn of 1990. The government has yet to announce any official decisions concerning the administration of the ceremonies. But it is said that the government intends to observe the traditional Shinto rites, in keeping with the precedent established in 1927, when Emperor Hirohito succeeded his father on the throne. The enthronement ritual of the new Emperor Akihito was held on November 12, 1990 as an official ceremony of state, enumerated by the tenth phrase of Article 7 of the Constitution. The traditional and secret Shinto ritual of Daijossai was performed at midnight on November 22, 1990. The debate occurred on the constitutionality of the decision of the government to finance this rite through the state budget.

4. These services were held on February 24, 1989.

5. 1947 Const. art. 20(3). 
The question of constitutionality proves highly troublesome in the case of the funeral services, which may to a certain degree accommodate the personal religious beliefs of the deceased. However, to ascend the throne is a purely official act. The constitutional principle of the separation of church and state must in this instance be strictly observed. We are now faced with the possibility of a reestablishment of continuity with the pre-1945 era in a very significant sphere of constitutional life.

\section{B. The Social Function of the Symbolic Emperor: The Question of Praeter Constitutionem Practices}

This question concerns the social effects generated by the very presence of the symbolic emperor. Of course, the Constitution does not treat this subject. Article 1 defines the emperor as "the symbol of the Japanese state and of the unity of the Japanese people." The word "unity," however, is understood to be devoid of any concrete juridical meaning. Furthermore, contrary to Rudolf Smend's doctrine of integration type unity, ${ }^{6}$ the word possesses no specific political character. Yet it remains no less true that in Japan the very presence itself of the emperor creates an atmosphere of integration, unity, and conformity within society, and that this praeter constitutionem phenomenon has a considerable effect upon constitutional life.

A remark is required concerning the drama created by the long illness and subsequent death of Emperor Hirohito, events that occurred from September 17,1988 , to January 7,1989 . A conformist attitude of a political nature spread astonishingly throughout Japanese society, particularly during the period of the emperor's illness. This phenomenon was due in large part to the amplifying effect produced by the mass media. Indeed, one witnessed a flood of inscription (kicho): Over ten million women and men rushed to sign the registers placed throughout the country to express their wishes for the emperor's recovery, and, later, their grief at his death. A wave of self-restraint (jishuku) disrupted daily life. The cancellation of countless sporting and cultural events, the postponement of several celebrities' wedding feasts, and the removal from broadcast of an automobile commercial beginning with the words "do you feel well" are but a few examples of this trend.

It would be wrong to interpret these gestures as signs of a renaissance of the cult of emperor worship. At issue rather is apolitical conformity that leads citizens to act in accordance with the mood of submissiveness and mourning systematically projected by the media. We are thus certainly not confronted with the revival of the kokutai in the moral sense of the word. However, it was precisely because they concerned the emperor that the media's initiatives were able to evoke such a considerable response from the citizens. Hence, it is possible to speak, while not in the strictly moral sense, at least in a psychosociological sense, of the continued existence of the kokutai.

6. R. SMEND, VERFASSUNG UND VERFASSUNGSRECht (1920). 
This conformist behavior is not necessarily passive, but may be accompanied by a consciousness, be it false or not, of participation. One weekly magazine quotes a twenty-two-year-old worker as saying, "This is a historic event .... I have lived this moment .... I signed the register in order to attest to that fact."

Within this climate of consensus occurred several incidents of major concern from a constitutional point of view. I will cite but one example. The mayor of Nagasaki, the city that along with Hiroshima was the victim of nuclear attack, was divested of his honorary functions in the local branch of the LDP because he asserted, in response to a question posed during debate in the municipal assembly, that Emperor Hirohito bore responsibility for the events of World War II. More serious is the fact that this conservative mayor had also to face the threats of right-wing extremists, who for several months surrounded the city hall with armored trucks whose loudspeakers blared deafening messages. ${ }^{7}$

As John Stuart Mill aptly indicated in his essay "On Liberty,"8 social tyranny (in which society itself becomes conformist) is an even greater threat to individuals' autonomy than are the visible constraints of political oppression. The unfolding of events in the highly industrialized East Asian archipelago threatens to confirm, after an interval of 130 years, the foresight of that unshakable Victorian liberal.

This observation, which from a constitutional perspective is essentially pessimistic, should all the same be tempered by the following remark. The wearing thin, if one may call it that, of the mood of premature mourning that lasted nearly four months finally permitted the appearance of more or less open debate. Curiously, the atmosphere was markedly less conformist during the official funeral services than it had been in the preceding months.

I will here close my remarks concerning the social conformism generated by the presence itself of the symbolic emperor. What will be the situation under the new emperor? I would like in closing to draw your attention to a particular aspect of the problem, namely, the role that the emperor himself might play with regard to constitutional revisionism.

7. On January 19,1990, as the mayor of Nagasaki left his office, he was shot and wounded by a member of a rightist group. He was hospitalized for the next three months. We have to cite another important case: Right-wing extremists threatened the President of the Meiji-Gakuin University because the University had decided not to do anything special for the time being regarding the emperor's coming death day, despite the fact that a number of events in society at large had been subject to "self-restraint." On this affair, see The Emperor System as a Japan Problem-The Case of Meiji Gakuin University, 5 RIME (Y. Sakamoto ed. 1989) (Occasional Papers Series, International Peace Research Institute Meigaku). And, finally, on the night of April 22, 1990, two shots were fired through the window of M. Yuge's home. M. Yuge, President of Ferris Women's College, had joined other Christian university presidents in Japan to issue a statement saying that the emperor's enthronement ceremonies should not be done in such a way as to violate the principle of the separation of religion and state.

8. J.S. Mill, ON Liberty (1935). 


\section{IV}

\section{Conclusion}

It is significant that, on January 9, 1989, during the solemn rite of succession, the new Emperor Akihito expressed to the representatives of the three branches of the state his desire to "defend the Constitution with [them]." Theoretically, one may not interpret the emperor's statements as expressions of his personal will, since, according to Articles 3 and 7 of the Constitution, all of his official acts require the "advice and consent" of the cabinet of ministers, under whose responsibility he is placed. The emperor's comments were greeted with much commotion, even more so in light of the fact that successive governments have been little given to expressing their respect for the nation's fundamental law, under which Japan has nonetheless achieved unprecedented economic growth, social stability, and also a measure of international credibility. The revisionists of the extreme right thus find themselves in a quandary and are struggling to reestablish their identity.

Will the emperor henceforth become the "symbol" of the defense of the Constitution without exceeding the limits imposed on him by that Constitution, which states that the emperor shall have no political character? The future will tell. 